\title{
VESTIGES OF LATE PRECAMBRIAN (OR YOUNGER) MICROFOSSILS IN CHERT OF THE LA TINTA FORMATION, NORTHEAST ARGENTINA
}

\author{
THOMAS R. FAIRCHILD
}

(Professor Visitante, Departamento de Paleontologia e Estratigrafia)

\section{INTRODUCTION}

Systematic examination of thin sections of silicified sediments in the palentology collections of the Institute of Geosciences, University of São Paulo (IG/USP) has revealed the presence of poorly preserved vestiges of probable microfossils in a light-gray chert from the La Tinta Formation of the Sierras Bayas, near Olavarría, NE Argentina. The microfossils include filaments, averaging about $40 \mu \mathrm{m}$, in diameter, and spheroidal and ellipsoidal microstructures of similar and larger sizes but of somewhat less certain biological origin. These are apparently the first microfossils reported from the La Tinta Formation. Although not comprising unequivocal evidence for age determinations, their presence is at least consistent with the late Precambrian age proposed for the formation by AMOS et al. (1971) and by MARCHESE and DI PAOLA (1975). Furthermore, the supposed La Tinta microfossils are sufficiently larger than silicified microfossils recently discovered in the Paraopeba Formation of the Bambuí Group of Brazil (FAIRCHILD and DARDENNE, this volume) to allow the hypothesis that the $\mathrm{La}$ Tinta Formation may be younger than the Paraopeba Formation. The discussion of these apparently biogenic microstructures from the La Tinta Formation hopefully will stimulate further micropaleontological studies of the Argentine Precambrian that one day may help establish a Precambrian biostratigraphic scheme for South America.

\section{GEOLOGIC SETTING AND AGE}

For many years the definition, extent, and age of the La Tinta Formation have been the source of much debate. Recently, MARCHESE and DI PAOLA (1975) proposed that the entire pre-Tertiary sedimentary sequence exposed in the more than $300 \mathrm{~km}$-long, NW-trending series of low mountains known as the Sierras Septentrionales, several hundred kilometers south of Buenos Aires, represents a single lithostratigraphic unit, the La Tinta Formation, of distinctly miogeosynclinal character. At the northwestern end of this range, in the Sierras Bayas-Olavarría region where the microfossiliferous chert was collected by U. G. Cordani (IG/USP), the La Tinta Formation rests nonconformably upon the altered granitic-migmatitic Buenos Aires Com- plex and comprises a nearly flat-lying sequence consisting of, in ascending order, $6-15 \mathrm{~m}$ of light-colored, cross-bedded quartzites; 4 to more than $30 \mathrm{~m}$ of dark-gray to yellowish, thick-bedded, primary dolostones with locally abundant stromatolites; $15-30 \mathrm{~m}$ of quartzites like those at the base; $5-30 \mathrm{~m}$ of variegated, laminated, illitic argillites; and, at the top, 15 to more than $50 \mathrm{~m}$ of black to grayish-red limestones, portions of which are silicified. The stratigraphic position of the microfossiliferous chert was not noted at the time of its colletion, but it apparently comes from the dolostones or from higher in the section (Cordani, pers. comm., 1978).

Stromatolites in the dolomitic member in the Sierras Bayas-Olavarría region were briefly described by AMOS et al. (1971) and more thoroughly documented by MARCHESE 
and Di PAOLA (1975). They are apparently most abundant near the top of the member, where they occur in lenticular beds up to $100 \mathrm{~m}$ long and exhibit a rich variety of morphologies, including Collenia and Cryptozoon (BONORINO, 1954, CUERDA, 1972, both apud MARCHESE and DI PAOLA, 1975), as well as unnamed, branched, columnar forms (MARCHESE and DI PAOLA, 1975). Up to five stomatolitic layers are evident locally, and individual stromatolites may reach $50 \mathrm{~cm}$ in transverse diameter. Columnar stromatolites also occur in the lower part of the dolomitic member. Careful study of the biostratigraphically significant columnar stromatolites may help resolve the problem of the age of the La Tinta Formation.

Prior to the suggestion by AMOS et. al. (1971) that the La Tinta stromatolites might indicate a Precambrian age, the $\mathrm{La}$ Tinta Formation was long considered to be Paleozoic in age, an assumption reinforced by BORRELLO'S discovery (1966, apud AMOS et al., 1971) of supposedly Ordovician ichnofossils in the southeastern part of the Sierras Septentrionales. The possibility of a Precambrian age for the formation has been further investigated by MARCHESE and DI PAOLA (1975) who argue that many of the "ichnofossils" are of doubtful biologic origin, that the La Tinta Formation is not correlatable with the generally fossiliferous, lower Paleozoic sequences of Argentina, and that the variety and abundance of stromatolites probably signify a Precambrian age for the formation. They suggest a very late Precambrian age of about 675 to $570 \mathrm{Ma}$, apparently partly in the belief that the formation slighty post-dates late Precambrian Brasiliano metamorphism (see ALMEIDA et. al., 1973, 1976). However, the cartonic block upon which the La Tinta Formation rests apparently was very little affected by the Brasiliano event (AlmeID A et al., 1973; Cordani, pers. comm., 1978), so that this event can not be considered as good geochronologic evidence for the formation's maximum possible age. Nevertheless, on the basis of the correlation of the La Tinta Formation with "Eocambrian" sequences in Brazil and Paraguay, ALMEIDA et al. (1973) arrived at an age very similar to that suggested by MARCHESE and DI PAOLA (1975). The formation is probably no younger than Ordovician, as it is intruded by a $450-500$ Ma-old (K-Ar ages) diabasic sill about $150 \mathrm{~km}$ $\mathrm{SW}$ of the Sierras Bayas-Olavarría area (R APELA et. al., 1974).

\section{METHOD OF STUDY}

The microfossils in the La Tinta Formation were studied in two petrographic thin sections (GP/L-3T-42 and 43) from a single hand sample (GP/3T-558) in the Paleontology Collection, IG/USP. The microfossils are too poorly preserved to be recoverable by acid maceration of the chert matrix.

\section{PRESERVATION OF THE MICROFOSSILS}

The microfossils are structurally preserved, but rather poorly so, with apparently little remaining of their organic matter (Figs. 1-5). They occur within a thin, beige lamina in crypto - to microcrystalline, light-gray chert with a waxy luster and well-developed conchoidal fracture. The microfossils are delimited by concentrated, submicron-sized grains of undetermined composition that define the 3-6 $\mu \mathrm{m}$-wide walls of the microfossils. Similar grains are also widely dispersed throughout the chert and appear to be mostly mineral grains deposited or formed prior to siliceous replacement of what was probably an originally carbonate sediment.

Photomicrographs of probable microfossils in a petrographic thin section of chert from the La Tinta Formation, Sierras Bayas, NE Argentina (Thin section no. GP/L-3T-43, Paleontology Collection, IG/USP). Scale in Fig. 1 also serves Fig. 2; that in Fig. 3 also serves Fig. 4.

Figs. 1,2, Overviews of areas with suspected microfossils, several of which are indicated by arrows.

Fig. 3, Close-up of spheroidal form shown in corner of Fig. 2.

Fig. 4, Elliptical outline of oblique cross-section through a poorly preserved filament.

Fig. 5, Closed, ellipsoidal body, possibly a microfossil. 


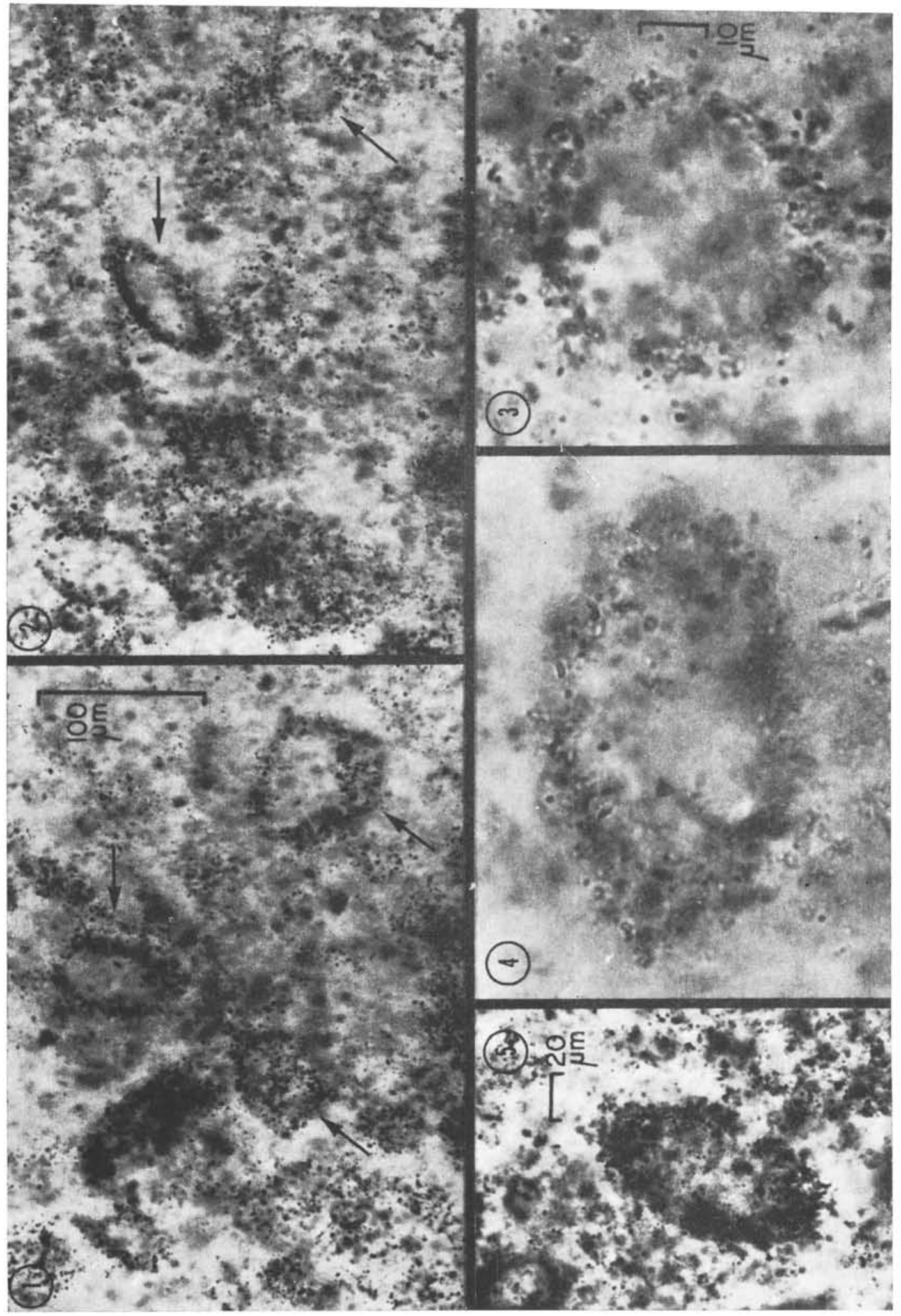


The filamentous microstructures (Fig. 4) exhibit a size range and morphology that suggest a biologic rather than a sedimentary origin. The ellipsoidal and spheroidal forms, on the other hand, are more difficult to interpret partly because of their less distinctive morphology. But many of these probably also represent microfossils, especially as they lack the dirty internal aspect of apparent clasts, have relatively smooth, regular outlines and margins (Figs. 1-3), and are preserved like the filamentous microfossils. These bodies lack vestigial crystalline textures or fabrics that might relate them to oolites or to siliceous spherulites. Their poor preservation, however, does not allow us to rule out completely a possible detrital origin for some of the closed bodies (?perhaps fig 5).

\section{THE MICROFOSSILS AND THEIR INTERPRETATION}

The microfossils are relatively abundant (Figs. 1,2) and are associated with some very fine sand-sized and silt-sized debris within a thin (1-2.5 mm thick), nonstromatolitic sedimentary lamina. Elliptical outlines (Fig. 4) commonly represent oblique sections of filamentous microfossils. These range in mininum outside diameter from 28 to $56 \mu \mathrm{m}(\mathrm{n}=20)$ and averange $39.6 \mu \mathrm{m}$. Few filaments have been observed in longitudinal section, possibly because their poor preservation makes them difficult to distinguish in this orientation. Nevertheless, one or two elongate microstructures interpreted as representing filaments appear to be possibly segmented, with the segments resembling some of the ellipsoidal microfossils. Straight cross-walls, branching, and intracellular organic matter have not been observed.

Spheroidal (Fig. 2,3) and ellipsoidal (Fig. 1,?5) microfossils similar in size to, or larger than, the filament diameters are also relatively common. Some closed bodies are possibly elongated bacillar microfossils, which would fit well with the possibly segmented (cellular?) character of some of the longitudinal filament sections. Superficial ornamentation and intracellular organic remains are not preserved.
On the basis of their simple morphology, small size, mode of preservation, similarity to other poorly preserved silicified microfossils (Fairchild, unpubl.), and lack of hard parts, the La Tinta microfossils probably represent algal remains rather than metazoan remains. Although their poor preservation prohibits close comparison with other fossil algae, the filamentous and unicellular forms are suficiently larger than the majority of modern procaryotic (cyanophytic) algal species (see SCHOPF, 1977) to suggest possible affinities with the evolutionarily more advanced eucaryotic (nucleated, mitotic) algae. When compared with the sizes reported for simple microfossils in silicified stromatolitic microfloras (SCHOPF, 1977), the relatively large size of both the filaments and the closed bodies in the La Tinta chert seems indicative of a very late Precambrian or younger age, probably less than $700 \mathrm{Ma}$. However, even though the microfossils occur within a stromatolite-bearing formation, they do not comprise a stromatolitic microflora, so that Schopf's scheme may not be fully applicable in this case. Nevertheless, the suggested age is consistent with that inferred by AMOS et al. (1971), ALMEIDA et al. (1973), and MARCHESE and DI PAOLA (1975).

The relatively large size of these microfossils also differentiates them from the much smaller microfossils in the recently discovered silicified microfloras of the Paraopeba Formation of the $>620$ Ma-old Bambuí Group in Brazil (FAIRCHILD and DARDENNE, this volume). This difference suggests, as a working hypothesis, that the La Tinta Formation quite possibly is younger than the Paraopeba Formation and therefore not correlatable with much of the Bambui Group. Comparative studies of stromatolites in these units should provide a good test of this hypothesis.

\section{SUMMARY AND CONCLUSIONS}

Filamentous and unicellular microfossils probably representing the poorly preserved remains of ancient algae occur in chert of the La Tinta Formation in NE Argentina. The relatively large size of these microfossils 
suggests a very late Precambrian (or younger) age for the La Tinta Formation, which is consistent with the ages inferred by certain previous workers. The microfossils are different from those in cherts of the Bambur Group (FAIR CHILD and DARDENNE, this volume), so that the correlations between the La Tinta Formation and this group (AMOS et al., 1971) may not be entirely valid. Because the studied material is both poorly preserved and of uncertain stratigraphic position within the formation, the observations and inferences made in this paper, rather than comprising firm conclusions, provide the bases for reasonable hypotheses whose confirmation will depend upon future study of carefully collected, better preserved material. Our Argentine collegues are encouraged, therefore, to take up the very interesting challenge presented by this difficult -to-study material.

Acknowledgments: I wish to thank F. F. M. de Almeida, G. Amaral, and U. G. Cordani of the IG/USP and C. L. Azcuy of the Universidad de Buenos Aires for helpful information. Special thanks go to A. C. Rocha-Campos (IG/USP) who first showed a paleontological interest in the La Tinta chert and who also provided financial support for this study through a grant from the Fundação de Amparo à Pesquisa do Estado de São Paulo.

\section{BIBLIOGRAPHY}

ALMEIDA, F. F. M. de, AMARAL, G., CORDANI, U. G. and KAWASHITA, K. - 1973 - The Precambrian evolution of the South American cratonic margin south of the Amazon river. In The Ocean Basins and Margins, vol. 1. Nairn, A. E. M. and Stehli, F. G. (eds.). Plenum Publishing Co., New York: 411-446.

ALMEIDA, F. F. M. de, HASUI, Y. and BRITO NEVES, B. B. de - 1976 - The upper Precambrian of South America. Bol. IG, Inst. Geociênc. Univ. São Paulo. 7:45-80.

AMOS, J. A., QUARTINO, B. J. and ZARDINI, R. A. - 1971 - El "Grupo La Tinta" (Provincia de Buenos Aires, Argentina) Paleozoico o Precambrico? Anais, XXV Congr. Bras. Geol. 1 : 211-221. São Paulo.

BONORINO, F. G. - 1954 - Geologia de las Sierras Bayas, Partido de Olavarria, Província de Buenos Aires. LEMIT. Série II, No 55.

BORRELlO, A. V. - 1966 - Paleontografia Bonarense. Fasc. V. Trazas, restos tubiformes y cuerpos fósiles problemáticos de la Formación de la Tinta. Sierras Septentrionales. Prov. Buenos Aires. Com. Inv. Cient. Prov. Buenos Aires.

CUERDA, A. J. - 1972 - Estudio biofacial comparado entre las faunas eopaleozoicas bonarenses y del Oeste Argentino. An. Soc. Cient. Arg. 194 (III-4): 105-115.

FAIRCHILD,T. R. and DARDENNE, M. A. - this volume - First report of well-preserved Precambrian microfossils in Brazil (Paraopeba Formation, Bambut Group, near Brasllia). Bol. IG. Inst. Geociênc. Univ. São Paulo.

MARCHESE, H. G. and DI PAOLA, E. C. - 1975 - Miogeosinclinal Tandil. Revista Asoc. Geol. Argentina. 30:161-179.

RAPELA, C. W., DALlA SALDA, L. H. and CINGOLANI, C. A. - 1974 - Un intrusivo básico ordovicico en la "Formación La Tinta" (Sierras de los Barrientos, Provincia de Buenos Aires, Argentina). Revista Asoc. Geol. Argentina. 29:319-331.

SCHOPF, J. W. - 1977 - Biostratigraphic usefulness of stromatolitic Precambrian microbiotas: a preliminary analysis. Precambrian Research. 5:143-173. 